\title{
Effects of Inverting the Position of Layers Eggs During Storage on Hatchery Performance Parameters
}

\section{Euthor(s)}

Lima JCS de

Silva $\mathrm{PL}^{2}$

Coelho LR ${ }^{1}$

Borges MS

Freitas $A G \mathrm{de}^{2}$

Fonseca $\mathrm{BB}^{2}$
Aluna do Curso de Pós Graduação em Ciências Aviárias da Universidade Federa de Uberlândia

2 Professor do Curso de Pós Graduação em Ciências Aviárias da Universidade Federa de Uberlândia

\begin{abstract}
Storing hatchable eggs is a common practice in commercial hatcheries. However, storage time may negative effects on several performance parameters. An experiment was carried out to evaluate inverting egg position during storage of eggs laid by young and old layer breeders. Fertile eggs of 32 and 58-week-old breeders were stored for seven, 14, and 21 days at $18^{\circ} \mathrm{C} \pm 2^{\circ} \mathrm{C}$ and $80 \% \pm 10 \%$ relative humidity (RU). The following parameters were evaluated: egg weight loss, hatchability and hatchling weight, and embryodiagnosis results. Eggs stored with the small end up lost less weight during storage compared with the control eggs. Storing eggs for 14 days with the small end up reduced early embryo mortality, improving hatchability. In addition, hatchling weight increased. These results show that the detrimental effects of long storage periods may be alleviated when eggs are stored with the small end up to 14 days of storage.
\end{abstract}

\section{INTRODUCTION}

The storage of hatchable eggs is a common, and often necessary, practice in commercial hatcheries. In general, the aim is to prevent mixing eggs from different flocks and ages and eggs from flocks with unknown health status, as well as to incubate a larger number of eggs to fit the commercial planning. However, stored eggs are influenced by several factors, including environmental conditions, genetics, flock age, egg chemical and physical characteristics, embryo development stage, and storage time, which will ultimately affect hatchability and hatchling quality (Schmidt et al., 2002).

The effect of storage on embryo viability involves embryo and egg quality losses, which may lead to blastoderm morphological changes, causing embryo malformations or death (Arora \& Kosin, 1966). Therefore, proper storage conditions are required to prevent any detrimental changes in embryo development resulting from long storage periods in order to obtain good incubation results.

Schmidt et al. (2002) suggested that evaporation could be reduced by turning the eggs with the small end up after seven days of storage. This would prevent the yolk, with the blastoderm on its surface, to float up and adhering to the air cell, in addition of reducing albumen water loss. This practice should be applied for eggs stored for periods longer than seven days, and obviously, the eggs need to be turned upside down before setting.

According to Michalsky et al. (2005), the relationship between layer breeder age and egg storage needs to be properly understood, because hatchability and hatchling quality are influenced by storage time, temperature, and humidity. However, scientific information on layer breeders is still scarce, and therefore, broiler breeder parameters are commonly applied in commercial hatcheries. 
The objective of this study was to determine if layer breeder eggs stored with the small end up influence egg weight loss during storage, hatchability, and average hatchling weight.

\section{MATERIALS AND METHODS}

In this trial, 1,800 hatchable eggs, derived from two flocks of commercial layer breeders and laid on the same day, were used. One flock consisted of young breeders (32 weeks of age), and the other of old breeders (58 weeks of age). In addition to breeder age, eggs were also divided as a function of storage time.

Hatchable eggs were individually weighed in a precision scale (Kern Emb. 220-1, 0.5 to 200 g). Egg weight classes were established according to breeder age: 54 to $62 \mathrm{~g}$ for 32 -week-old breeder eggs, and 63 to $72 \mathrm{~g}$ for 58-week-old breeder eggs. Eggs were identified and their weights were entered in a spreadsheet as initial weight.

Eggs of young and old breeders were stored for seven, 14, and 21 days. Out of the 300 eggs per storage period, 150 were considered as controls and were stored with the small end down, whereas the other 150 were considered the test group and were stored with the large end down. Eggs were stored in the egg room with temperature and humidity control $\left(18^{\circ} \mathrm{C} \pm 2^{\circ} \mathrm{C}\right.$ and $\left.80 \% \pm 10 \% \mathrm{RH}\right)$.

At the end of each storage period, eggs were again individually weighed and placed in the correction position for setting (small end down and air cell up). Eggs were immediately transferred to a pre-heating aisle, where they remained for eight hours. The aisle was located between the incubation room and egg-storage room. Heating aisle temperature was maintained between $25^{\circ} \mathrm{C} \pm 3^{\circ} \mathrm{C}$ and relative humidity $(\mathrm{RH})$ between $70 \% \pm 20 \%$.

Eggs were set in an incubator (Petersime ${ }^{\circledR}$ ) with 25,200 -egg capacity at $99.0^{\circ} \mathrm{F}$ dry-bulb temperature and $86^{\circ} \mathrm{F}$ wet-bulb temperature. During the incubation period, egg position within the machine was changed, and the incubator was filled to the capacity with eggs that were not included in the experiment. Eggs were transferred from the incubator to the hatcher after 456 hours of incubation in a single procedure. Trays with eggs from all treatment groups were placed in a single hatcher (Petersime ${ }^{\circledR}$ KK168), with 16,800-egg capacity and temperature set at $24.8^{\circ} \mathrm{C}$ and $\mathrm{RH}$ at $67 \%$. Eggs from each treatment group were placed in individual hatching trays, which were duly identified.

Chicks were removed from the hatcher after 510 hours of incubation ( 21 days +6 hours). Chicks were removed according to treatment for weighing and grading. Non-hatched eggs were returned to the hatcher, where they remained for further 14 hours. After that period, hatched chicks were removed, and the non-hatched eggs were submitted to embryodiagnosis.

Hatchlings were classified as viable chicks or rejects. Culling criteria included unhealed navel, lameness, blindness, and ectopic viscera. Chicks were considered viable when free from any pathology at inspection.

Hatchability was calculated as according to the equation: (hatched chicks/incubated eggs) x 100 . Chicks were placed in duly identified trays according to treatment group and grading. Hatchlings were counted and weighed on the same aforementioned precision scale.

Embryo mortality rate and stage were determined at the end of the incubation period in all nonhatched eggs as a function of treatment. These eggs were classified as infertile; early, intermediate or later mortality; non-hatched (pipped eggs with live embryo, pipped eggs with dead embryo); malposition; malformation; or cracked.

Data on egg weight loss during storage and hatchling weight were submitted to analysis of variance and means were compared by the test of Tukey $(p<0.05)$. Hatchability and embryodiagnosis results were analyzed by binomial test between two ratios, at $5 \%$ significance level. Statistical analysis was carried out using the software program Bioestat version 5.0 (Ayres et al., 2007).

\section{RESULTS AND DISCUSSION}

Egg weight loss at arrival at the hatchery and during incubation of both young and old breeders stored for 7 and 14 days (Table 1). The test groups presented lower egg weight loss relative to the controls. No statistical differences were detected for egg weight loss when eggs were stored for 21 days. In addition, at this storage time, there was $100 \%$ embryo mortality in both treatment groups.

Table 1 - Effects of storage time of eggs stored with the small end up produced by young and old layer breeders on egg weight loss ( $\mathrm{g}$ ).

\begin{tabular}{ccccc}
\hline \multirow{2}{*}{ Breeder age } & \multicolumn{4}{c}{ Storage time } \\
\cline { 2 - 5 } & Control & Test & Control & Test \\
\hline & $0.6073^{\mathrm{a}}$ & $0.5100^{\mathrm{b}}$ & $1.3227^{\mathrm{c}}$ & $1.2247^{\mathrm{d}}$ \\
\hline Young & $1.0967^{\mathrm{a}}$ & $0.8517^{\mathrm{b}}$ & $1.3227^{\mathrm{c}}$ & $1.1607^{\mathrm{d}}$ \\
\hline Old & ${ }^{2}$ &
\end{tabular}

$a, b$ : means followed by different letters in the same row are statistically different at $p<0.05$. 
Control eggs lost more weight during storage, as previously observed by Schmidt et al. (2002), who found that storing eggs with the small end up for more than seven days reduces evaporation, hindering albumen water loss, and consequently reduces egg weight loss during storage.

Hatchability was different between the test and the control groups both for young and old breeders when eggs were stored for 14 days: the control group presented higher early mortality and lower hatchability compared with the test group. Early embryo mortality was responsible for this difference, as shown in the results presented in Tables 2 to 5.

Table 2 - Effect of seven days of storage of eggs stored with the small end up produced by young layers on hatchability and embryo mortality.

\begin{tabular}{ccccc}
\hline Group & $\begin{array}{c}\text { Early } \\
\text { mortality (\%) }\end{array}$ & $\begin{array}{c}\text { Intermediate } \\
\text { mortality }\end{array}$ & $\begin{array}{c}\text { Late } \\
\text { mortality }\end{array}$ & Hatchability \\
\hline Control & $3.66^{\mathrm{a}}$ & $0^{\mathrm{a}}$ & $5.33^{\mathrm{a}}$ & $90.33^{\mathrm{a}}$ \\
\hline Test & $1.67^{\mathrm{a}}$ & $0^{\mathrm{a}}$ & $3.35^{\mathrm{b}}$ & $92.28^{\mathrm{a}}$ \\
\hline
\end{tabular}

Means followed by different letters in the same column are statistically different.

Table 3 - Effect of seven days of storage of eggs stored with the small end up produced by old layer breeders on hatchability and embryo mortality.

\begin{tabular}{ccccc}
\hline Group & $\begin{array}{c}\text { Early } \\
\text { mortality (\%) }\end{array}$ & $\begin{array}{c}\text { Intermediate } \\
\text { mortality }\end{array}$ & $\begin{array}{c}\text { Late } \\
\text { mortality }\end{array}$ & Hatchability \\
\hline Control & $3.36^{\mathrm{a}}$ & $0^{\mathrm{a}}$ & $0.67^{\mathrm{a}}$ & $93.60^{\mathrm{a}}$ \\
\hline Test & $1.67^{\mathrm{a}}$ & $0^{\mathrm{a}}$ & $0.67^{\mathrm{a}}$ & $96.97^{\mathrm{b}}$ \\
\hline
\end{tabular}

Means followed by different letters in the same column are statistically different.

Table 4 - Effect of 14 days of storage of eggs stored with the small end up produced by young layer breeders on hatchability and embryo mortality.

\begin{tabular}{ccccc}
\hline Group & $\begin{array}{c}\text { Early } \\
\text { mortality (\%) }\end{array}$ & $\begin{array}{c}\text { Intermediate } \\
\text { mortality }\end{array}$ & $\begin{array}{c}\text { Late } \\
\text { mortality }\end{array}$ & Hatchability \\
\hline Control & $20.06^{\mathrm{a}}$ & $0.68^{\mathrm{a}}$ & $5.78^{\mathrm{a}}$ & $67.68^{\mathrm{a}}$ \\
\hline Test & $9.06 \mathrm{~b}$ & $1.00 \mathrm{a}$ & $5.36^{\mathrm{a}}$ & $81.54^{\mathrm{b}}$ \\
\hline
\end{tabular}

Means followed by different letters in the same column are statistically different.

Table 5 - Effect of 14 days of storage of eggs stored with the small end up produced by old layer breeders on hatchability and embryo mortality.

\begin{tabular}{ccccc} 
Group & $\begin{array}{c}\text { Early } \\
\text { mortality (\%) }\end{array}$ & $\begin{array}{c}\text { Intermediate } \\
\text { mortality }\end{array}$ & $\begin{array}{c}\text { Late } \\
\text { mortality }\end{array}$ & Hatchability \\
\hline Control & $18.12^{\mathrm{a}}$ & $0^{\mathrm{a}}$ & $2.34^{\mathrm{a}}$ & $78.18^{\mathrm{a}}$ \\
\hline Test & $11.68^{\mathrm{b}}$ & $0^{\mathrm{a}}$ & $2.35^{\mathrm{a}}$ & $84.17^{\mathrm{b}}$ \\
\hline
\end{tabular}

Means followed by different letters in the same column are statistically different.

Hatchability results were better in the test group than in the control group. The hatchability of fertile eggs stored for 14 days with the small end down was lower due to higher embryo mortality, particularly early mortality. In old breeders, the test group also obtained better hatchability results when eggs were stored for seven days; however, the main cause of embryo mortality was the high percentage of pipped eggshells, i.e., fully formed embryos that did not emerge. Brake et al. (1997) mentioned that the higher hatchability of eggs stored with small end up may be associated with a more central position of the yolk as well as to the location of the blastoderm at the equatorial region of the egg. They also reported that, in eggs of older breeders, the blastoderm reaches the equatorial region of the egg easier due to their thinner albumen.

Although there are few literature reports relating long egg storage periods and egg inverted postition during storage, the study of Elibol \& Brake (2008) showed positive effects of egg turning in the preincubation period. They reported a $6.6 \%$ increase in the hatchability of egg stored for 14 days that were turned 96 times per day, and reported that storing the eggs with the small end up improved hatchability, particularly when long storage periods were used.

Hatchling weight was higher in eggs of young breeders stored for 14 days and of old breeders stored for seven days when they were stored with small end up (Table 5).

Table 6 - Effect of storage time of eggs stored with the small end up produced by young and old layer breeders on hatchling weight (g).

\begin{tabular}{cccc}
\hline Storage period & Breeders age & Control & Test \\
\hline \multirow{2}{*}{7 days } & Young & $41.76^{\mathrm{a}}$ & $41.77^{\mathrm{a}}$ \\
\cline { 2 - 4 } & Old & $45.085^{\mathrm{a}}$ & $46.018^{\mathrm{b}}$ \\
\hline \multirow{2}{*}{14 days } & Young & $40.2^{\mathrm{a}}$ & $41.012^{\mathrm{b}}$ \\
\cline { 2 - 4 } & Old & $46.31^{\mathrm{a}}$ & $46.44^{\mathrm{a}}$ \\
\hline
\end{tabular}

Means followed by different letters in the same row are statistically different.

Christensen et al. (2002) concluded that there is a decrease in embryo body weight and in the capacity of the embryo to produce energy and to utilize egg nutrients as storage period increases, affecting the growth potential of several tissues during incubation. According to Elibol et al. (2002), eggs stored for short periods (2 to 4 days) do not require special management; however, longer storage periods require special techniques to be applied, such as using a turning system in the egg storage room.

In the present study, there was a positive effect of storing eggs with the small end up on the weight of chicks derived from old breeders' eggs stored for seven days, and from young breeders' eggs stored for 14 days. Considering the lower egg weight loss, storing young breeders' eggs with the small end up may improve hatchling quality. 
In commercial poultry production, long egg storage times are sometimes unavoidable due to flock logistic issues and market availability. Therefore, storing eggs from young breeders may be an option to reduce losses relative hatchling weight and hatchability.

\section{CONCLUSIONS}

Storing eggs with the small end up is an alternative method to improve hatchability and to reduce egg weight and hatchling weight losses in eggs derived from young and old breeders stored up to 14 days.

\section{REFERENCES}

Arora, K.; Kosin I. Changes in the gross morphological appearance of chicken and turkey blastoderms during pré incubation storage. Poultry Science 1966; 45:819-825.

Ayres M, Ayres Jr M, Ayres DL, Santos, AAS. Bioestat 5.0: Aplicações estatísticas nas áreas das ciências biomédicas. 6. ed. Belém, 2007.

Biezus, AJ. Incubatório. 2001. Available at: http://www.aviculturaindustrial. com.brdinamica.asp?id=1688\&tipo_tabela=produtos\&categoria=avicu Itura_postura. Accessed in: 30 set. 2010.

Brake JT, Walsh TJ, Benton Jr CE, Petite JN, Meiherhof R, Penalva G. Egg handling and storage. Poultry Science 1997; 76:144-151.

Christensen VL, Wineland MJ, Fasenko GM, Donaldson WE. Egg storage alters weight of supply and demand organs of broiler chicken embryos. Poultry Science 2002; 81:1738-1743.

Meijerhof R, Noordhuizen JPTM, Leenstra FR. Influence of preincubation treatment on hatching results of broiler breeder eggs produced at 37 and 59 weeks of age. Brazilian Poultry Science 1994; 35:249-257.

Elibol, O. e brake, J. Effect of egg position during three and fourteen days of storage and turning frequency during subsequent incubation on hatchability of broiler hatching eggs. Poultry Science, v. 87, n. 6, 2008, p. 1237-1241.

Michalsky V.B. Efeitos da umidade relativa do ar na incubadora e da idade da matriz leve sobre o rendimento da incubação e desempenho da progênie. 63f. [Dissertação]. Escola de Veterinária, Belo Horizonte (MG): Universidade Federal de Minas Gerais; 2005.

Mujeer AK, Kothandaraman P, Sethumadhavan V, Gajendran K, Narahari D. Effect of certain pre-incubation storage conditions on hatchability of chicken eggs. Poultry Science 1986, 21:215-218.

North MO, Bell DD. Maintaing hatching egg quality. In: Commercial chicken production manual. New York: Chapman \& Hall; 1990. p. 31 - 44

Proudfoot FG. Advance note on the hatchability of chicken eggs stored small end up. Canadian Journal of Animal Science 1967; 47:142-143.

Proudfoot FG. The handling and storage of hatching eggs: The Fertility and Hatchability of the Hens' Egg. T. C. Carter and B. M. Freeman, ed. Oliver and Boyd, Edinburgh, UK; 1969; p. 127-141.

Romanoff AL. The Avian Embryo. Structural and Functional Development. MacMillan Co., New York, NY, 1960.

Schmidt GS, Figueiredo EAP, Avila VS. Incubação: estocagem de ovos férteis. Embrapa - Comunicado Técnico, n. 303, 2002, 5 p.
Tona K, Bamelis F, Ketelaere B De, Bruggeman V, Moraes VM, Buyse J, Onagbesan O, Decuypere E. Effects of egg storage time on spread of hatch, chick quality, and chick juvenile growth. Poultry Science 2003; 82:736-741. 